\title{
A THICK FILM BASE METAL RESISTOR AND COMPATIBLE HYBRID SYSTEM
}

\author{
F. E. BUZAN, J. D. GRIER, Sr., B. E. BERTSCH and H. THORYK \\ Cermalloy Division, Bala Electronics Corp., W. Conshohocken, Pa., U.S.A.
}

(Received May 31, 1977)

\begin{abstract}
Non-noble metal thick film materials have been the topic of several recent papers. ${ }^{11}, 13,14,15$ This paper will focus on the first non-noble metal thick film system comprising conductors, dielectrics and most important, resistors for commercial use. Processing and performance data are presented in detail to illustrate the capabilities of these new materials. Circuit applications information is presented wherever possible. This new class of materials will enable the microelectronics industry to exploit new market opportunities previously unavailable due to the high costs of precious metal materials.
\end{abstract}

\section{INTRODUCTION}

To assure the continued growth of the hybrid microelectronics industry, continued efforts to achieve lower manufacturing costs must be stressed. Obviously, direct material costs of a thick film circuit vary greatly, but it is a safe assumption that material cost is always a significant portion of the total circuit cost. The elimination of precious metal materials to achieve passive circuit functions is now a reality. Commercially available base metal compositions now offer the circuit manufacturer a viable alternative to noble metal thick films. The use of nonnoble materials in the electronics industry is neither new nor unique. ${ }^{1-6}$

Several well known examples are the use of Copper plating depositions in the printed circuit board industry and the use of Tin Oxide, Indium Oxide ${ }^{7}$ and Thallium Oxide ${ }^{8-9}$ to manufacture resistive elements. Unfortunately, these earlier products were not marketed as a thick film system, but as individual materials. ${ }^{16}$ The development of a conventionally screen printed and fired base metal system is a new and viable concept. The necessary processing equipment such as atmosphere furnaces have been available for several years. ${ }^{10}$

Development of this system utilizes conventional methods of thick film material manufacturing in which finely divided particles of metals and glasses are dispersed in an organic medium. The materials are then processed into a screen printable paste form just as their noble metal counterparts. Some of the resultant base metal products exhibit performance characteristics equivalent to noble metal materials. Specific improvements have been made in the Copper conductor to permit routine printing of 4 mil lines with 4 mil spacings. ${ }^{11}$ This line resolution capability is equivalent to the state of the art in printing noble metal conductor materials.

This paper will define the characteristics, capabilities, and economics of a base metals approach to thick film technology. Each part of the system, i.e., resistors, conductors, and dielectrics will be examined ard defined. Specific circuit applications, as well as potential applications utilizing this base metal system will be discussed.

\section{THE NPS BASE METALS SYSTEM}

The NPS base metals system comprises the following materials:

\section{A. NPS Resistors}

\begin{tabular}{lccc}
\hline $\begin{array}{l}\text { Part } \\
\text { no. }\end{array}$ & $\begin{array}{l}\text { Resistivity } \\
\text { (ohms/sq.) }\end{array}$ & $\begin{array}{l}\text { TCR } \\
\left(\mathrm{ppm} /{ }^{\circ} \mathrm{C}\right)\end{array}$ & $\begin{array}{l}\text { Viscosity } \\
\text { (poise) }\end{array}$ \\
\hline 7150 & $35-65$ & +350 & 1000 \\
7200 & $85-115$ & +300 & 1000 \\
7300 & $850-1150$ & +150 & 1000 \\
7400 & $8.5 \mathrm{~K}-11.5 \mathrm{~K}$ & \pm 50 & 1000 \\
7500 & $80 \mathrm{~K}-120 \mathrm{~K}$ & -600 & \\
\hline
\end{tabular}


B. NPS Conductors

\begin{tabular}{llll}
\hline $\begin{array}{l}\text { Part } \\
\text { no. }\end{array}$ & $\begin{array}{l}\text { Resistivity } \\
\text { (ohms/sq.) } \\
\text { (microns-thick) }\end{array}$ & Metallurgy & $\begin{array}{l}\text { Viscosity } \\
\text { (poise) }\end{array}$ \\
\hline 7028 & $\begin{array}{l}0.060 \text { at } 20 \\
7029 \mathrm{~d}\end{array}$ & $\begin{array}{l}\text { Nickel } \\
\text { 0.003 at } 18\end{array}$ & $\begin{array}{l}3000 \\
\text { Copper }\end{array}$ \\
\hline
\end{tabular}

\section{NPS Dielectrics}

\begin{tabular}{lccccc}
\hline $\begin{array}{l}\text { Part } \\
\text { no. }\end{array}$ & $\begin{array}{l}\text { Dielectric } \\
\text { constant } \\
\text { (K) }\end{array}$ & DF $^{\text {a }}$ & IR (ohms) & TCC $^{b}$ & $\begin{array}{l}\text { Viscosity } \\
\text { (poise) }\end{array}$ \\
\hline 7115 & $9-10$ & 0.005 & $10^{13}$ & +350 & 2000 \\
$7115 \mathrm{~B}$ & $7.5-8.5$ & 0.010 & $10^{12}$ & +700 & 2000 \\
\hline
\end{tabular}

\footnotetext{
a Measured at $1 \mathrm{kHz}$.

$\mathrm{b}+25^{\circ} \mathrm{C}$ to $+85^{\circ} \mathrm{C}$.
}

The many processing similarities between the NPS systems and the more familiar noble metal systems will not be discussed. Instead, important differences and the dissimilarities will be presented in some detail.

Fortunately, the systems differ in only two areas: namely, the drying process and the firing process.

The processing of finely divided base metal particles at elevated temperatures requires additional precautions not required with precious metals. For example, consider the following reactions in air at about $500^{\circ} \mathrm{C}$ for 5 micron powders:

$$
\begin{aligned}
\mathrm{Cu}^{\circ}+1 / 2-\mathrm{O}_{2} \text { (air) } & \longrightarrow \mathrm{\Delta} \mathrm{CuO} \\
\Delta \mathrm{H}_{0}= & -37740 \text { gm cal. mole }{ }^{-1} \\
\mathrm{Au}^{\circ}+\mathrm{O}_{2} \text { (air) } & \longrightarrow \mathrm{Au}^{\circ}
\end{aligned}
$$

One can readily see that in Eq. (1) Copper Oxide will be formed quite easily as evidenced by the very large negative heat of formation $\left(\Delta \mathrm{H}_{0}\right)$. Gold metal remains unchanged and will not form stable oxides at these temperatures.

This information is presented to demonstrate that base metals are prone to oxidation when exposed to excessive temperatures during processing. Actual experience has shown that if one establishes a reproducible, precise drying schedule for processing these base metal thick films, results will be consistent. Inconsistent drying operations produce variations in oxide films and yield unsatisfactory results. A recommended drying sequence is $150^{\circ} \mathrm{C}$ for 5 minutes when drying resistor and conductor materials. A 10 minute drying time at the same temperature is recommended when processing dielectric materials.

After drying, firing in a Nitrogen atmosphere is necessary to prevent oxidation of the dried films. Optimum firing conditions are $900^{\circ} \mathrm{C}$ for 6 minutes dwell for all NPS materials. Permissible processing range is $875^{\circ} \mathrm{C}-925^{\circ} \mathrm{C}$ over a dwell time of $6-8$ minutes. Many furnace manufacturers produce equipment capable of maintaining the desired Nitrogen cover. An earlier paper ${ }^{10}$ has shown that the cost of providing Nitrogen cover gas in the furnace to be about $\$ 0.90 / \mathrm{hr}$. at gas flow rates of $150 \mathrm{SCF} / \mathrm{hr}$. $\left(4.85 \mathrm{~m}^{3} \mathrm{hr}^{-1}\right)$. These flow rates will adequately process at least $500-1 \times 2$ inch substrates per hour.

A qualitative comparison between conventional air injected furnaces and Nitrogen furnaces suggests approximate cost equality when one considers cost of compressor operation, air dryers, filters, etc. In addition, the cost of Nitrogen gas is negligible when compared with the thick film material savings that can be realized.

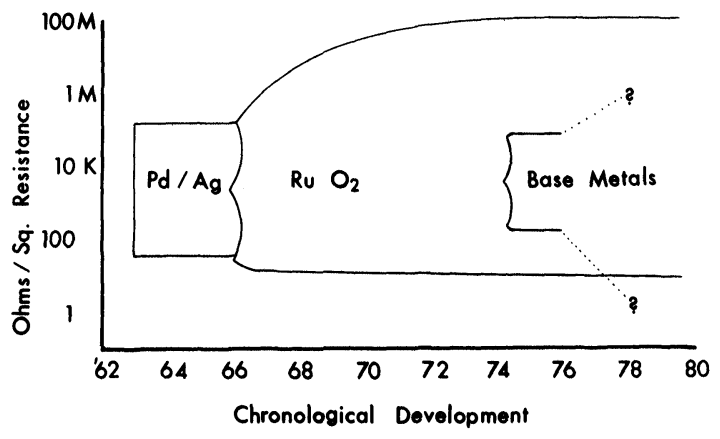

FIGURE 1 Chronological development of materials for thick film resistor compositions.

$\begin{array}{lc}\text { A. Conductor Compositions } & \text { Relative Cost } \\ \text { Copper } & 100 \\ \text { Nitkel } & 83 \\ \text { Silver } & 56 \\ \text { Palladium Silver } & 139 \\ \text { Gold } & 1055 \\ \text { B. Resistor Compositions } & \\ \text { NPS } & 100 \\ \text { Ruthonium Oxide } & 209 \\ \text { Cost } & \text { 100 } \\ \text { Precious motal prices - January 1977 }\end{array}$

FIGURE 2 Materials cost comparison for thick film compositions. 
Figure 1 illustrates the chronological development of commercially available thick film materials. Significant resistor production using base metal or refractory metal materials has been achieved for many years by various companies ${ }^{12}$ using proprietary base metal materials. This point is made to demonstrate the feasibility of this approach.

Figure 2 illustrates the relative material cost of the base metal system and the more widely used noble metals. For comparison purposes, approximate cost at a 3 kilogram purchased material level is presented.

As acceptance of these materials occur in the market place and production economies are realized, resistor materials should sell for less than $\$ 10.00$ per ounce, and conductors should sell for less than currently available silver conductors.

A number of applications areas have been identified for NPS materials. These will be amplified in the last section of this paper. Microwave strip line circuits multilayer interconnection circuitry, capacitor terminations, and D.C. gas display panels are current applications areas for existing materials. Near term opportunities for base metal products include telecommunications circuits, low cost resistorconductor networks, and metallization of porcelanized steel substrates.

\section{SYSTEM COMPONENTS}

\subsection{NPS Resistor}

3.1.1 General The availability of a resistor system that is compatible with Copper and Nickel metallizations is an important step in achieving a truly low cost thick film paste system. The Cermalloy NPS resistor system consists of a finely divided glass, with Tantalum metal, plus other base metal oxides for TCR and resistivity control.

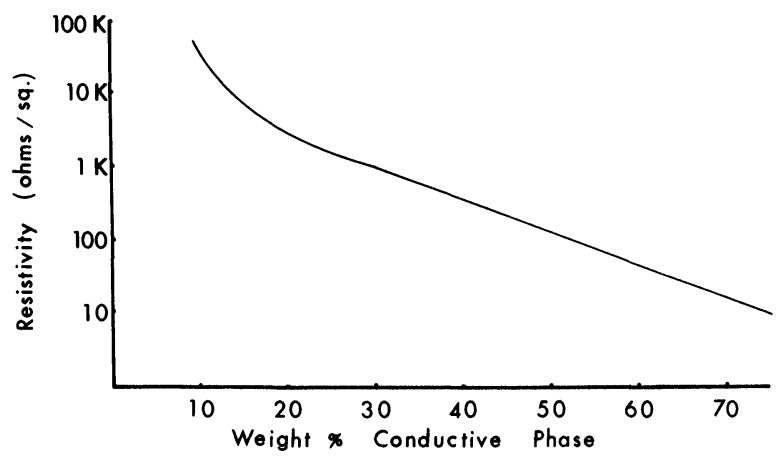

FIGURE 3 Sheet resistance vs. weight percent of conductive phase.

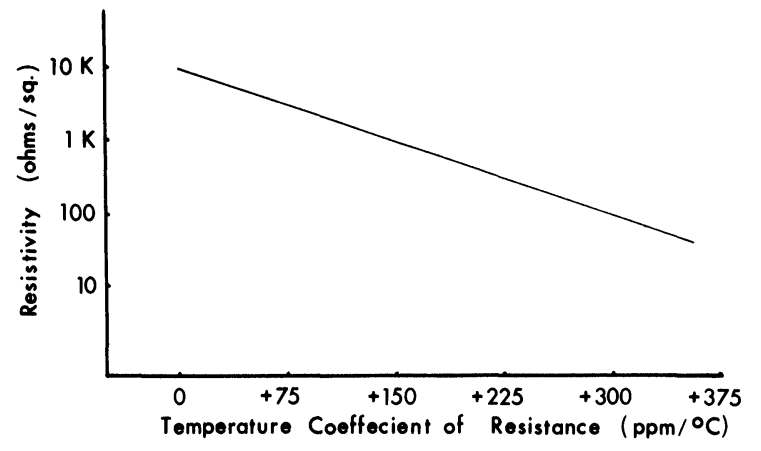

FIGURE 4 Sheet resistance vs. TCR.

Figure 3 shows the relationship between resistivity and the conductive phase present. This curve typifies most thick film resistor materials currently available.

Figure 4 depicts the TCR vs. resistivity relationship. Reasonably good TCR performance is shown up to $10-20 \mathrm{kohm} / \mathrm{sq}$. after which strongly negative TCR's at $100 \mathrm{kohm}$ per square are observed. Presently, work is in progress to correct this limitation. Note the hot side and cold side TCR values nearly coincide over the entire resistivity range.

The following table illustrates typical processing conditions used to generate data in this paper.

\section{Cermalloy NPS Resistors}

\begin{tabular}{ll}
\hline Recommended screen & 200 mesh stainless steel \\
Substrate composition & $96 \%$ Aluminum Oxide \\
Print thickness (dry) & $30-33$ microns \\
Print thickness (fired) & $16-18$ microns \\
Drying schedule & $150^{\circ} \mathrm{C}$ for 5 minutes \\
Furnace Nitrogen consumption & $150 \mathrm{SCFH}\left(4.85 \mathrm{~m}^{3} \mathrm{hr} .^{-1}\right)$ \\
Firing temperature & $900^{\circ} \mathrm{C}$ \\
Dwell time & 6 minutes \\
Conductor composition & Cermalloy 7029 Copper \\
\hline
\end{tabular}

Figure 5 illustrates the effect of peak firing temperature on sheet resistivity. The resistivity varies

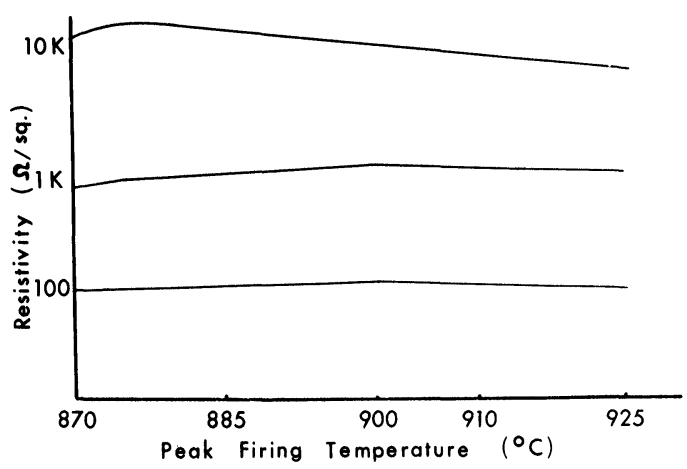

FIGURE 5 Sheet resistance vs. peak firing temperature. 


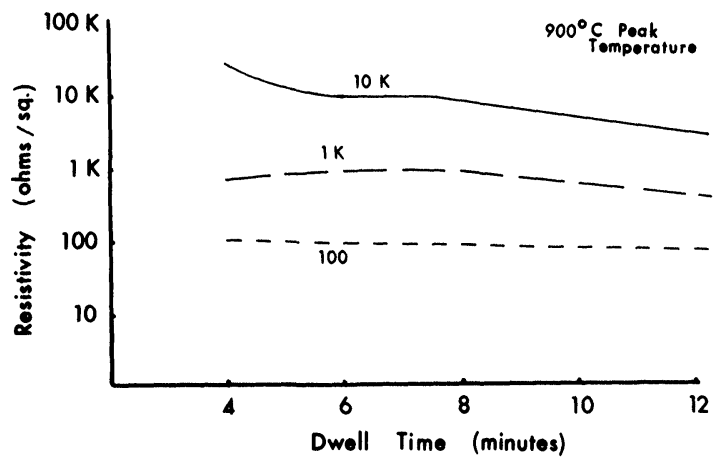

FIGURE 6 Sheet resistance vs. dwell time at peak firing temperature.

$0.5 \%$ per ${ }^{\circ} \mathrm{C}$ change in peak firing temperature over firing temperatures from $870^{\circ} \mathrm{C}$ to $925^{\circ} \mathrm{C}$. This change is comparable to air firing Ruthenium Oxide materials.

Figure 6 illustrates the effect of dwell time at peak firing temperature on sheet resistivity. Variation of dwell time for the 100 and $1000 \mathrm{ohm}$ materials causes negligible changes in resistivity. However, the resistivity of $10 \mathrm{kohm}$ material decreases as the time at peak temperature increases.

\subsubsection{Resistor stability The following data illus-} trate resistor system stability under various stress situations. Test data accumulated to date suggests a drift rate of less than $0.5 \%$ after 1000 hour exposure to ambient of $150^{\circ} \mathrm{C}$. This is presented graphically in Figure 7, showing individual resistivity ranges tested.

Load life testing at 100 watts/sq.in. for 100 hours at $70^{\circ} \mathrm{C}$ is presented in Figure 8 . Resistance changes here are less than $2 \%$. Humidity testing when passivated with a Cermalloy 5200 epoxy cover coat minimizes resistivity changes. Less than $1 \%$ change in 1000 hours of exposure to a $95 \%$ relative humidity

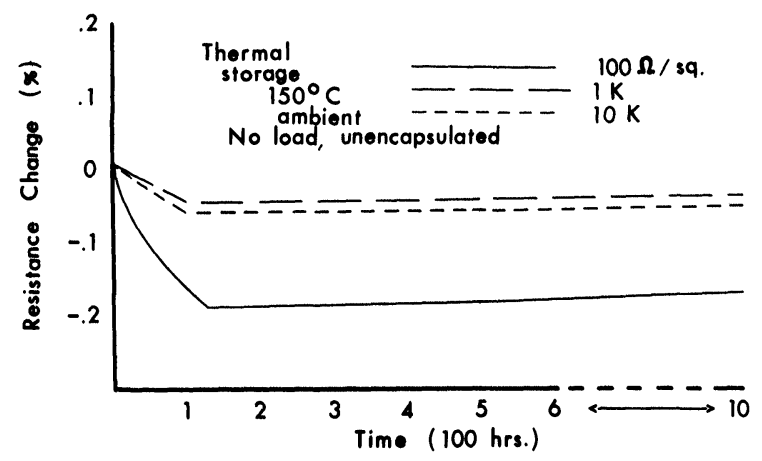

FIGURE 7 Effect of various stress environments on resistance.

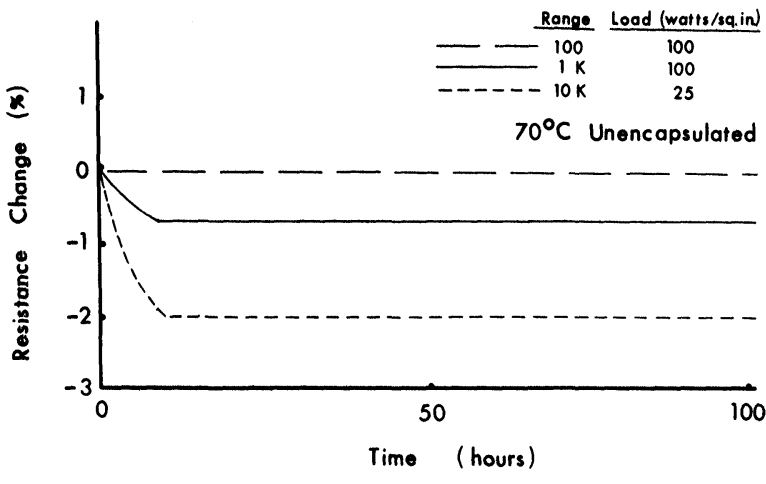

FIGURE 8 Change in resistance with time on load.

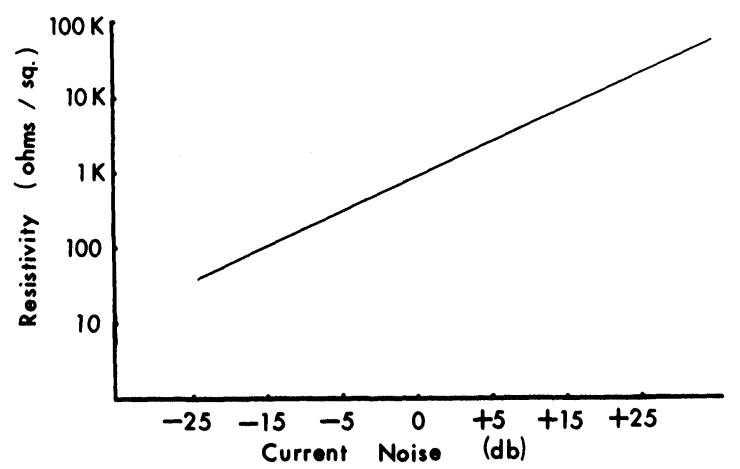

FIGURE 9 Sheet resistance vs. current noise.

environment, is a typical performance when properly passivated.

Exposure to humidity or moisture will produce undesirable resistance changes if the resistor surface is not properly passivated. The effect of solder exposure on NPS resistors is typically a $0.1 \%$ change after 10 second immersion in $60 \mathrm{Sn} 40 \mathrm{~Pb}$ solder at $250^{\circ} \mathrm{C}$.

The current noise characteristics are presented in Figure 9. This data shows the NPS resistors have a higher noise level than presently used Ruthenium Oxide resistors. This difference is undoubtedly due to the particle size and shape of the NPS resistors relative to the more highly developed Ruthenium Oxide materials with smaller particle size. Future work with smaller particulate NPS materials may improve the noise characteristics of this system.

3.1.3 Trimming characteristics Abrasive trimming can be accomplished in the same manner as other thick film materials, using standard techniques.

Limited experience with laser trimming indicates that a higher than conventional power level is necessary to satisfactorily remove the more refractory materials contained in NPS resistors. 
A Union Carbide Corpl Model No. KRT Q switching type laser trimmer was used to provide a simple plunge cut configuration. As-fired resistor values were noted and a $20 \%$ trim resistance adjustment was made. This percentage of trim provides a trim configuration adequate to show variation in resistor performance due to trimming.

The laser trimming parameters selected are as follows:

$\begin{array}{ll}\text { Peak Power } & 1.8 \mathrm{~kW} \\ \text { Repetition Rate } & 260 \mathrm{~Hz} \\ \text { Linear Trim Rate } & 50 \mathrm{Mils} / \mathrm{sec} . \\ \text { Laser Cut Type } & \text { Single plunge }\end{array}$

The following tabulation summarizes the data. Notice that both the 100 hours room temperature drift, as well as 500 hour $-150^{\circ} \mathrm{C}$ drift are less than $0.25 \%$.

\begin{tabular}{llll}
\hline $\begin{array}{l}\text { Initial } \\
\text { R value (ohms) }\end{array}$ & $\begin{array}{l}\text { 20\% trimmed } \\
\text { value (ohms) }\end{array}$ & $\begin{array}{l}100 \text { hour } \\
\text { room temp. } \\
\text { avg. drift-\% }\end{array}$ & $\begin{array}{l}500 \text { hour } \\
\text { at } 150^{\circ} \mathrm{C} \\
\text { avg. drift-\% }\end{array}$ \\
\hline 125 & 150 & \pm 0.1 & 0.23 \\
$1.4 \mathrm{~K}$ & $1.7 \mathrm{~K}$ & \pm 0.1 & 0.08 \\
$8.4 \mathrm{~K}$ & $10.0 \mathrm{~K}$ & +0.2 & 0.06 \\
\hline
\end{tabular}

\subsection{Conductors}

3.2.1 Copper conductor 7029 The specific properties of the Copper conductor, Cermalloy 7029 have been elucidated in recent papers by Grier ${ }^{13}$ and Wood ${ }^{11}$ and hence will be presented here only in summary form. For greater detail, it is suggested that these references be consulted.

A Copper thick film conductor material can be a truly high performance, low cost product. The conductivity of 7029 Copper is 3.2 milliohms per square at 15 microns fired thickness and is comparable to

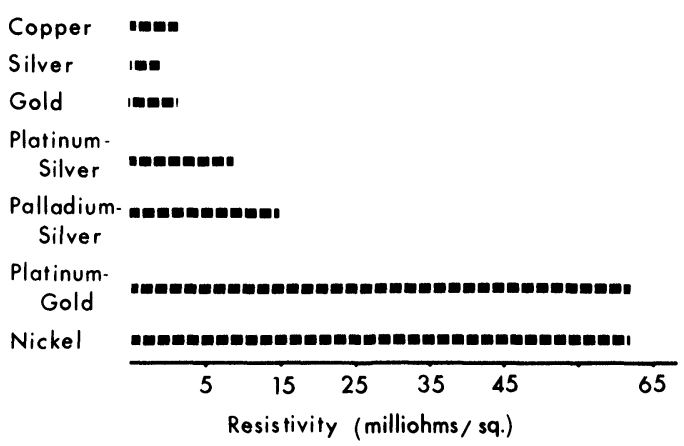

FIGURE 10 Sheet resistance for various thick film metallisations.

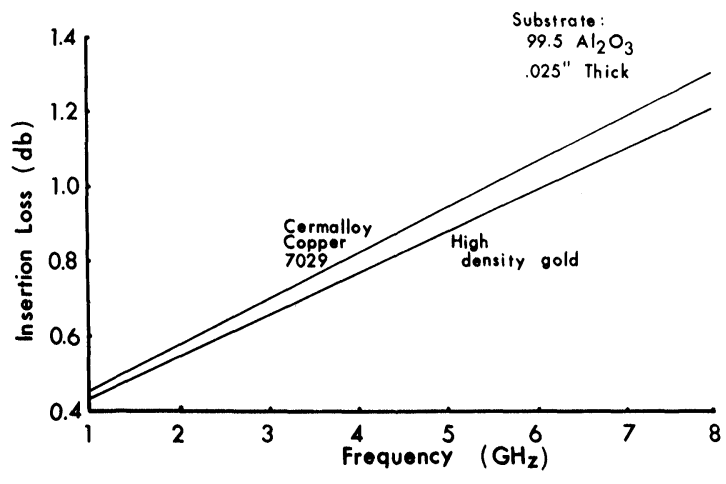

FIGURE 11 Insertion loss vs. frequency for two types of conductors.

thick film Gold conductors. Figure 10 contrasts the resistivity of several thick film metallizations available in the market. This exceptionally high conductivity value of 7029 Copper has permitted its use in circuits from $\mathrm{DC}$ to at least $8 \mathrm{GHz}$ at a great cost savings over thin film Chrome/Gold and high density thick film Gold stripline approaches.

Figure 11 shows the actual difference in microwave insertion loss between 7029 Copper and a commercial thick film Gold, over the frequency of 1 to $8 \mathrm{GHz}$.

Figure 12 shows fine line capability of Copper on an Alumina substrate. Line widths as small as 4 mils (100 microns) are easily resolved.

In addition to being a highly conductive material, the 7029 Copper also wire bonds over reasonably broad processing parameters. ${ }^{17}$ Figures 13 and 14 show initial and aged wire bond strengths in grams for 1 mil Aluminum wire. Note that the loss of adhesion due to ageing at $155^{\circ} \mathrm{C}$ for 168 hours is negligible.

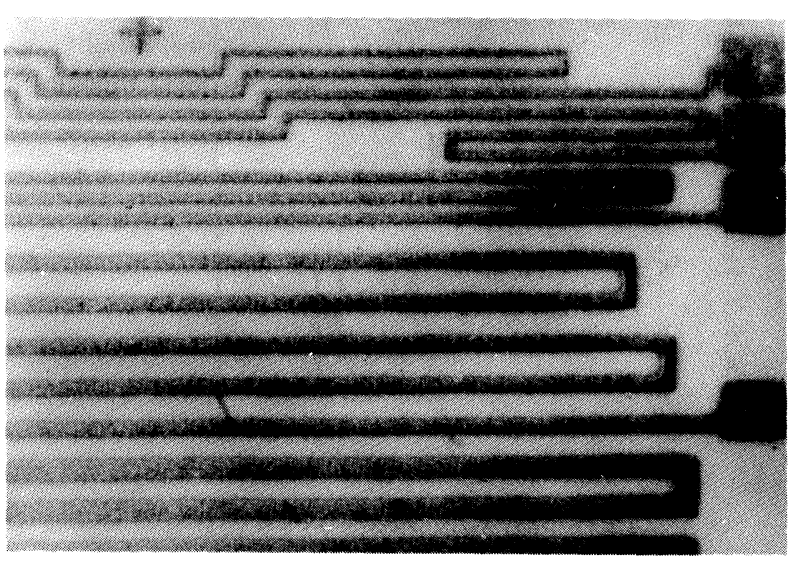

FIGURE 12 Copper conductor printing on alumina (the smallest line width shown is $100 \mu \mathrm{m}$ ). 


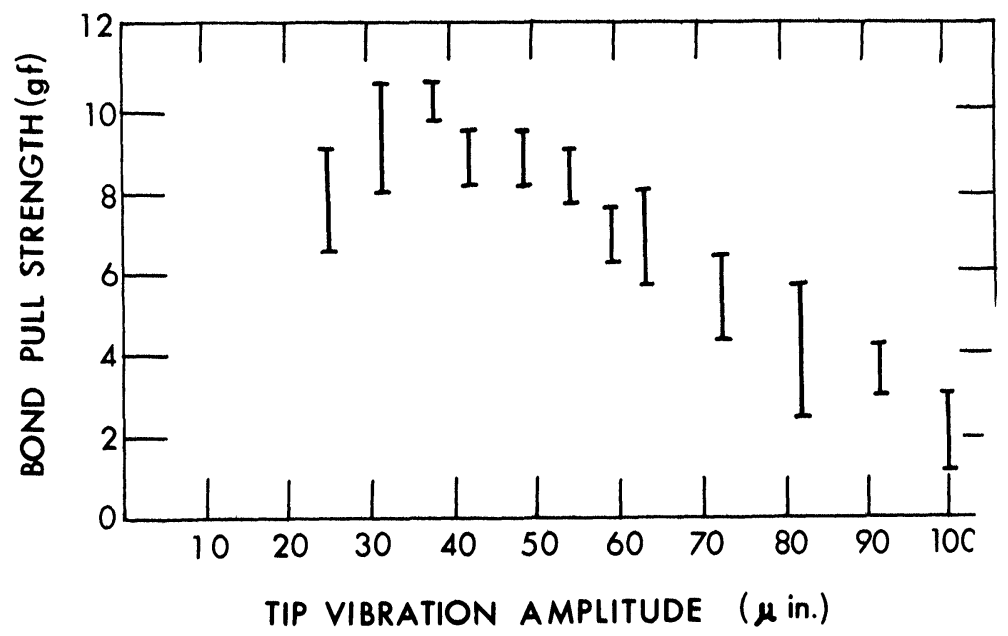

FIGURE 13 Initial wire bond vs. vibration amplitude of bonding tool (copper conductors and aluminium wire).

Similar results are obtained on soldered adhesion peel tests using $100 \mathrm{mil}^{2}\left(2.5 \mathrm{~mm}^{2}\right)$ pads and a $60 \mathrm{Sn} 40 \mathrm{~Pb}$ solder composition. Figure 15 typifies results of a 2000 hour $150^{\circ} \mathrm{C}$ solder ageing test revealing negligible loss of adhesion. This feature of the Copper suggests possible use for high reliability applications where soldered circuitry is exposed to high ambient operating temperatures. The adhesion retention after prolonged high temperature exposure is an outstanding advantage of this material, which should be exploited.

Wood ${ }^{9}$ has evaluated various plating techniques for compatibility with Copper thick film and found electroplating Gold to be acceptable, while electroless Gold

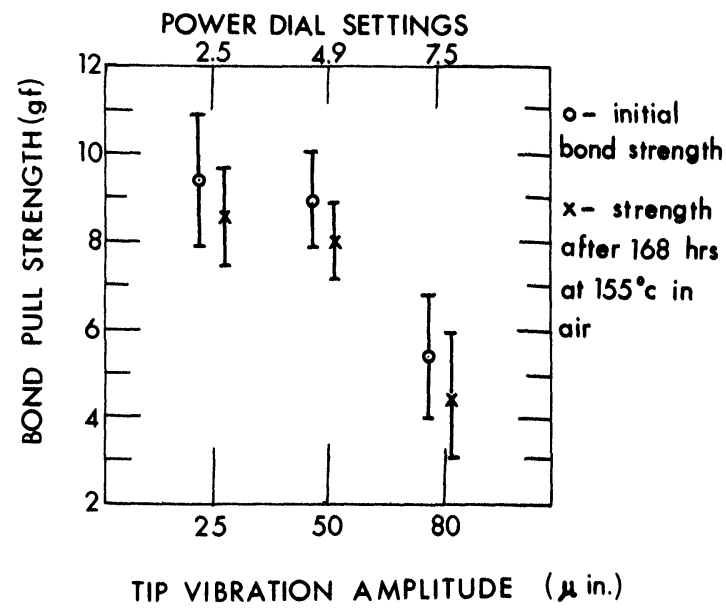

FIGURE 14 Aged wire bond strength vs. vibration amplitude of bonding tool (copper conductors and aluminium wire).

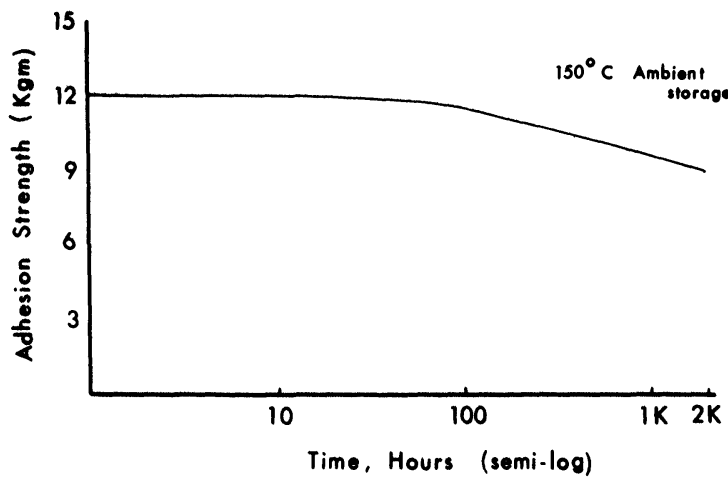

FIGURE 15 Adhesion strength vs. time. Copper conductors stored at $150^{\circ} \mathrm{C}$.

and Tin plating processes attacked the Copper and caused adhesion degradation.

3.2.2 Nickel conductor 7028 The thick film Nickel conductors are widely used as electrode material for D.C. gas discharge display panels. This conductor is normally fired onto soda-lime glass substrates at temperatures not exceeding $600^{\circ} \mathrm{C}$ for display panel applications.

As a termination material for NPS resistors, it is capable of being fired at $900^{\circ}-950^{\circ} \mathrm{C}$. Nickel conductors are typically more difficult to solder, less adherent to the substrate and considerably less conductive than Copper materials and hence have found limited applications.

\subsection{Dielectrics}

The development of Nitrogen firing dielectric pastes 


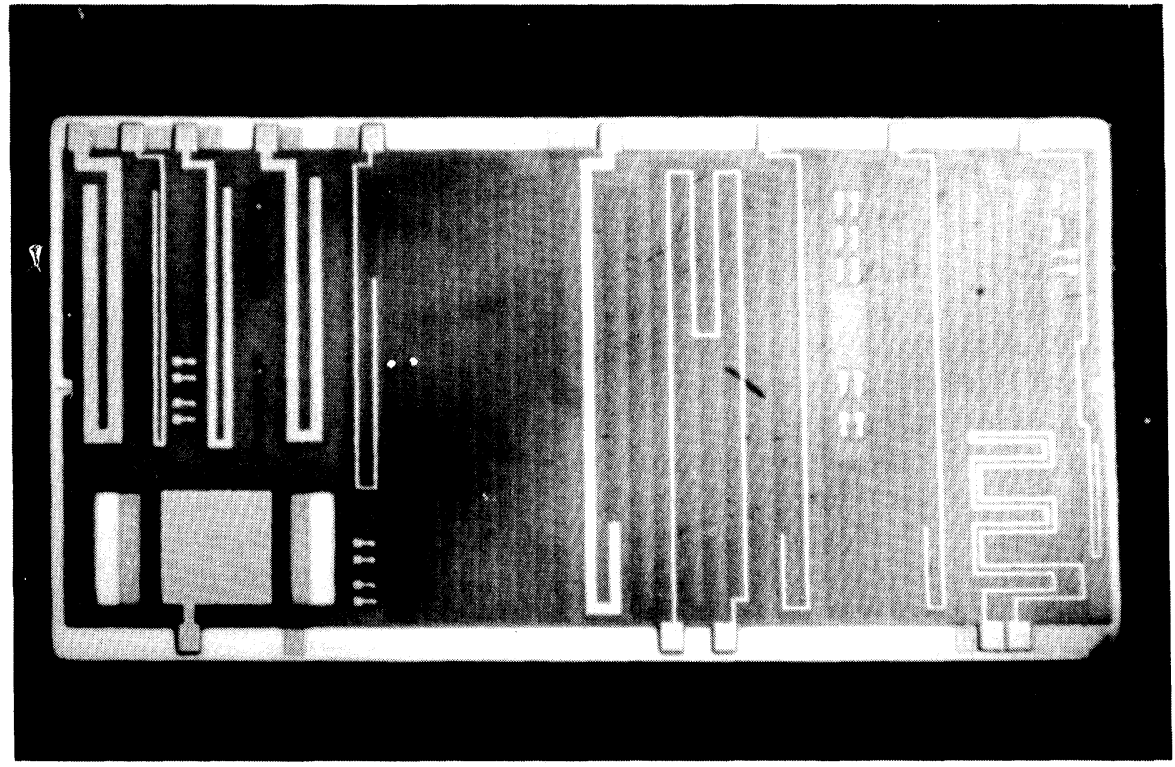

FIGURE 16 Two metallisation layer multilayer test circuit (for magnification see Figure 17).

permits the manufacture of complex multilayer circuitry for interconnection applications. Cermalloy dielectric compositions 7115 and $7115 \mathrm{~B}$ have been designed to be compatible with Copper 7029 while closely matching the expansion characteristics of a 96\% Aluminum Oxide substrate to minimize substrate distortion problems. The electrical properties of these materials were summarized in Section 2 of this paper. The proper processing of dielectric materials is of prime importance if high circuit yields are expected.
The printing and drying processes should occur in a clean, dust free environment. The following processing conditions are recommended to obtain high yield multilayer circuits using either 7115 or $7115 \mathrm{~B}$ dielectric materials:

1) Clean substrates prior to printing dielectric material.

2) Print 2 wet passes per dielectric layer.

3) Dry at $150^{\circ} \mathrm{C}$ for 10 minutes.

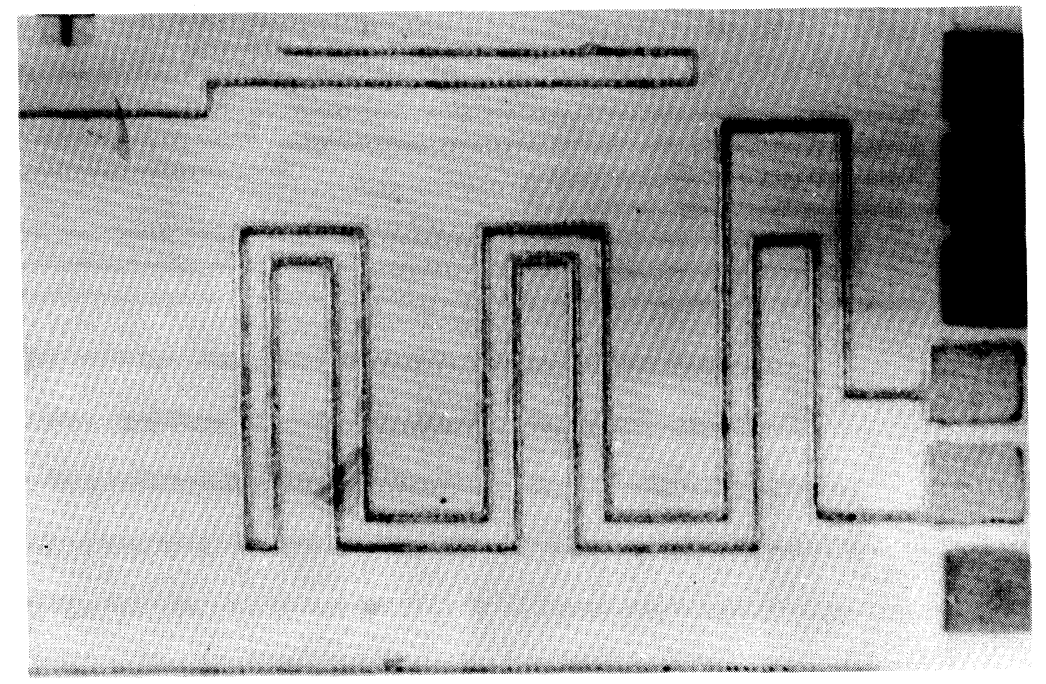

FIGURE 17 Detail of two metallisation layer multilayer test circuit (copper conductor lines in upper right are $100 \mu \mathrm{m}$ wide). 
4) Fire at $900^{\circ} \mathrm{C}$ for 7 minutes dwell in $150 \mathrm{SCFH}$ flowing Nitrogen gas.

5) Repeat steps 2, 3 and 4.

6) Total fired deposition thickness to be $40-50$ microns.

Experience has indicated that a separate firing of Copper conductor on top of the dielectric is preferred to cofiring to eliminate or minimize materials interactions. Cofiring generally contributes excessive material reactions and reduces product yields.

A $12-15$ mil via resolution capability is characteristic of these dielectric materials. Very large substrate sizes, for example 4 in. $\times 4$ in., appear to iimit resolution of vias to 15 mils.

Figure 16 illustrates a simple 2 metallization layer multilayer test circuit utilizing 7115B dielectric and 7029 Copper materials. This circuit has been processed in accordance with the above instructions. Figure 17 shows greater detail of the completed circuit, using 7115 dielectric. The Copper conductor lines in the upper right are 100 microns wide. These particular circuit materials constitute the basic multilayer capability of this system. The 7115B is a denser, lower $\mathrm{K}$ dielectric material than 7115 and it fires to a permanent blue colour. The 7115B also permits easier solderability of Copper on top of the dielectric. The adhesion strength of the soldered Copper on top of $7115 \mathrm{~B}$ is superior to that on top of 7115. We suspect these differences are due to the greater film density and opacity of the 7115B.

Actual production experience using either dielectric with the 7029 Copper conductor has demonstrated that multilayer circuitry can be manufactured at high yields using base metal conductors.

\section{SYSTEM APPLICATIONS}

Previously, several application areas were identified as being suitable for, and compatible with the NPS system characteristics. These include microstrip circuitry up to at least $8 \mathrm{GHz}$, high density interconnections, resistor-conductor networks, high power diode metallization, terminations for capacitors, D.C. gas display panels, solar cell metallization materials, metallization for enamelled stainless steel substrates, and metallization for Beryllia ceramics.

The primary advantages of a Nitrogen processable resistor system are that it provides for the use of inexpensive Copper and Nickel conductors and that, it is itself a low cost system. This becomes apparent when one considers that the conductor material usually constitutes the largest material cost in the circuit.

Figure 18 shows a typical stripline circuit configuration having some moderate area printing, and conductor traces 25 and 10 mils $(0.62$ and $0.25 \mathrm{~mm})$ in width. The conductor traces should be uniform to \pm 1 mil ( \pm 25 microns) in width. The fired conductor film density should be high with a fired thickness of from 0.7 to 1.0 mils (18 to 25 microns). As shown earlier, the Copper is comparable in performance to thick film Gold and thin film Chrome-Gold for most microstrip circuits up to the low $\mathrm{GHz}$ frequencies. Furthermore, the use of Copper eliminates the necessity of expensive Indium bearing solders and permits the use of common Tin-Lead solders. The NPS resistors are ideally suited for such high frequency circuits since the performance characteristics of the desired lower resistance range $(10 \mathrm{ohms}$ to 1000 ohms) are competitive to the presently used air fired

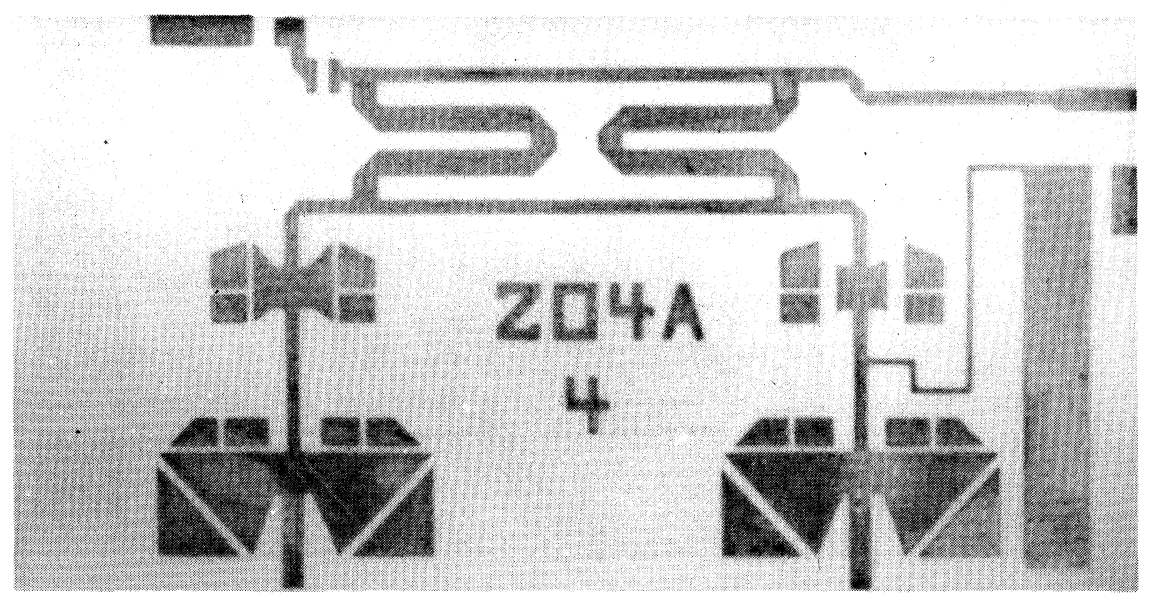

FIGURE 18 Typical strip line circuit configuration (conductor traces 0.62 and $0.25 \mathrm{~mm}$ wide). 


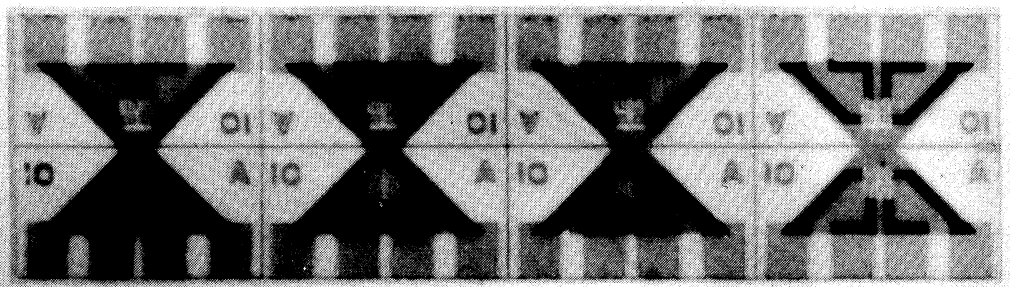

FIGURE 19 Copper metallised circuit which provides for flip chip reflow solder attachment of 4 bump integrated circuit chips.

systems. Thus, screen printing of NPS resistors directly onto the Copper microstrip circuits is feasible.

A wide variety of characteristics are monitored during the fabrication of circuits; of greatest concern are: maintaining high conductivity with thin conductor traces, solderability and adhesion of top conductors, and good dielectric via control. This system provides thin conductor traces of better than 3 milliohms per square with dielectric-conductor adhesion strengths ty pically over 8 pounds peel on a $100 \mathrm{mil}^{2}\left(2.5 \mathrm{~mm}^{2}\right)$ peel test. The dielectric material is glassy and therefore has a high cohesive film strength necessary for over printing metallizations.

Copper thick film is compatible with certain capacitor compositions of the non-reduced Titanate

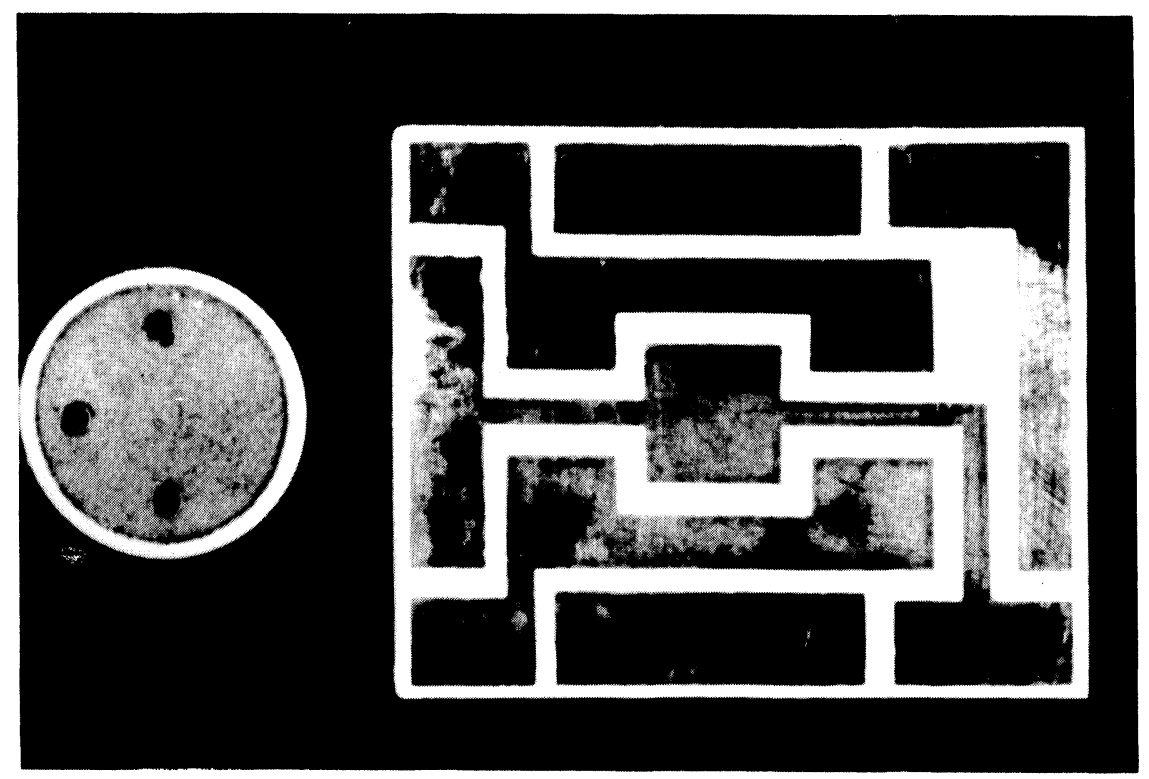

FIGURE 20 Two examples of high power circuit metallisation. 


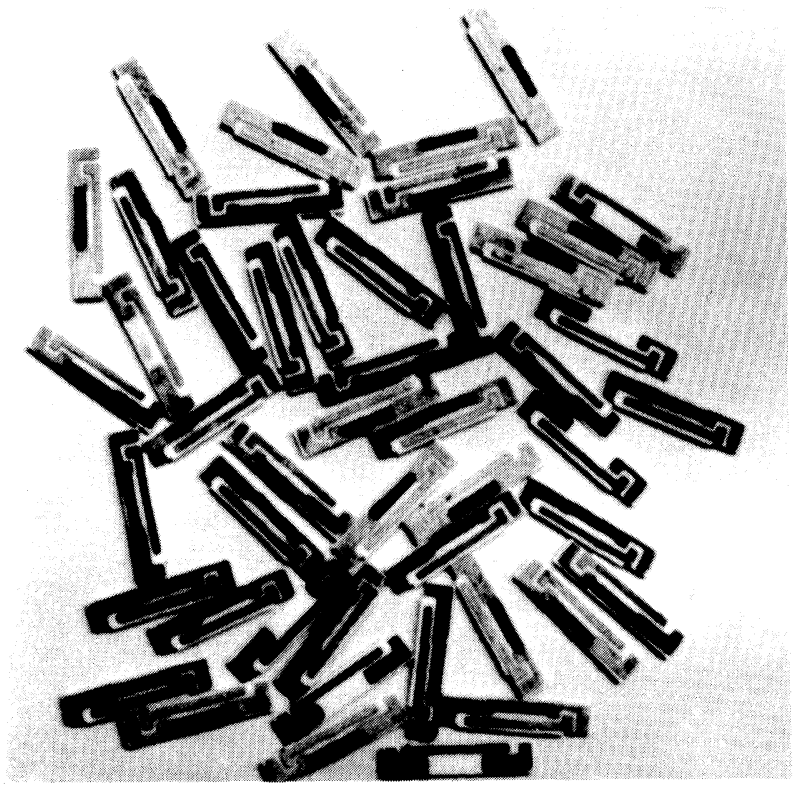

FIGURE 21 Base metal resistors terminated to copper or nickel conductors ( 0.75 in. $\times 0.13$ in.).

variety. Ultimately, the Copper paste used would be cost competitive with presently used Silver metallizations. In addition to the cost advantage, Copper would considerably suppress problems arising from characteristic metal price fluctuations.

The Copper metallized circuit shown in Figure 19 provides for flip chip reflow solder attachment of a four bump integrated circuit chip. A reflow solder attached package cap may be employed as a means of protecting the chip here.

Figure 20 shows two examples of high power circuit metallizations. The large substrate shown in the upper part of the picture is 96\% Alumina with high adhesion Copper. The disc is Beryllia using the same Copper metallization material. Each circuit accommodates a reflow solder attached high power chip. The metallization used for reflow solder attachment of high power integrated circuit chips such as SCR's is usually plated Moly.Manganese. A single print of Copper will provide such a circuit with the additional advantage of an efficient thermally conductive metallization. The Copper is a mix-bonded formulation, providing little resistance to heat dissipation.

The small parts $(0.75 \times 0.13$ inches $)$ shown in Figure 21 are printed with base metal resistors terminated to Copper or Nickel conductors. This configuration is used in trigger switches for variable speed drill and saw motors.

Large quantities of thick film Nickel and black dielectric are presently being used in the manufacture of D.C. panels. Nickel is fairly non-reactive to Mercury, which is present in D.C. gas panels. This is an advantage as well as the low cost and low processing temperature on soda-lime glass. Other volume applications are displays for point-of-sale computer cash registers and CRT games. These materials are processed on plate glass at about $600^{\circ} \mathrm{C}$. A variety of
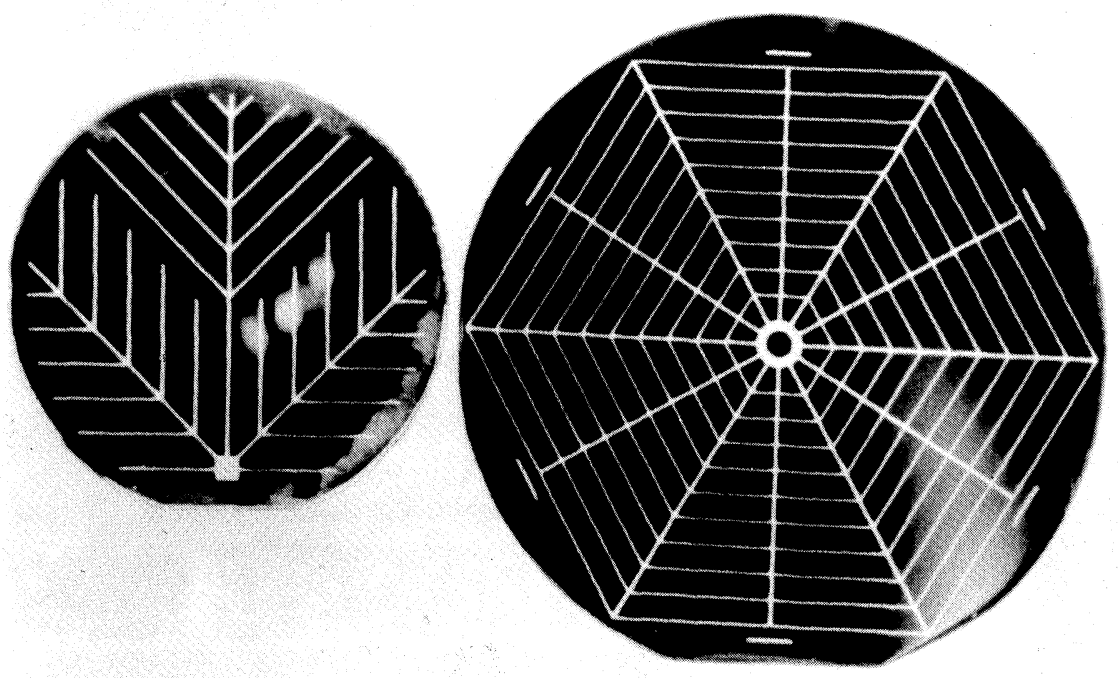

FIGURE 222 in. and 3 in. diameter silicon solder cells with copper thick film electrodes. 
multiplexing circuit configurations are employed, using the multilayer capability.

Figure 22 shows both 2 and 3 inch diameter Silicon solar cells having Copper thick film electrodes. The "sun-side" of such a cell typically has a shallow diffusion layer to maximise cell efficiency. Because of this, the conductor material required for electroding must be compatible with the lower temperature processing conditions and with the Silicon system to protect the junction characteristics. Present uses of panels and cells include power supply to remote electronic instruments, construction bridge structure, biasing to prevent galvanic degradation and (arid region) water pumping power units. If other problems relating to cost and efficiency can be solved, a very large potential for electronic materials may evolve.

The technological area which lies between P.C. board circuits and hybrid thick film circuits may be described as requiring the large area of a P.C. board and the high temperature and flexural stability of a ceramic circuit. Porcelanized steel substrates using base metal conductors may well fill this technological gap. Fabrication of these circuits combine the advantages of low temperature processing $\left(<600^{\circ} \mathrm{C}\right.$ peak temperature), low cost substrates, low cost base metal conductors, selective metal deposition, solderability, through-hole printing and long term thermal and mechanical stability.

\section{CONCLUSION}

A compatible base metal thick film hybrid materials system is presented in this paper. It comprises Nickel and Copper conductors, dielectric for multilayer and low capacitance and a base metal resistor paste. Particular emphasis is placed on the resistor characteristics in as much as it is the newest and probably the most sophisticated member of the system. Although substantial refinements in further paste development and processing conditions are indicated, it is believed that this hybrid system, in its present form, represents a useable and dependable new approach to the manufacture of hybrid circuitry today.

Base metal pastes are no longer considered a novelty. Nickel and Copper conductors have been used successfully in product manufacturing for over two years. It is reasonable to project not only a sig- nificant increase in cost effectiveness with the use of these materials, but certain technical advantages which are shown in this paper will widen the range of opportunities for thick film technology.

\section{REFERENCES}

1. Constant TCR thick film thermistor, U.S. Pat. 3932312 , Casimir M. Kazmierowicz, Techman Inst., Fullerton, Ca.

2. Varistor compositions, U.S. Pat. 3,900,432, Sanford M. Marcus, Frank K. Patterson, E.I. Dupont Co., Wilmington, Del.

3. Oxide varistor, U.S. Pat. 3899451, Noboru Ichinose, Yuhji Yokomizo, Toshiba, Kawasaki, Japan.

4. Film resistor and method, U.S. Pat. 3924221, Ernel R. Winkler, Corning Glass, Corning, N.Y.

5. Metallizing refractory substrates, U.S. Pat. 2993815 , A. W. Treptow, Bell Telephone Labs, New York, N.Y.

6. Electroless copper deposition, U.S. Pat. 3383224, Oleh B. Dulkewych, Shipley Co., Newton, Ma.

7. Indium oxide glaze resistors, M. L. Bock and A. H. Mones, IBM. Presented at American Ceramic Society, Oct. 27-29, 1965, Los Angeles, Ca.

8. Thallium oxide glaze containing an additive of $\mathrm{RuO}_{2}$, U.S. Pat. 3352797, Kee Hyong Kim, Air Reduction Co., New York, N.Y.

9. Thallium oxide resistive glazes, F. M. Collins, M. F. Redmount, Air Reduction Co., Niagara Falls, N.Y. Presented ISHM, Boston, Ma. October, 1967.

10. Dual atmosphere furnaces for firing base metal pastes, H. Howard Beck, BTU Engineering Corp., N. Billerica, Ma. Presented at ISHM, Nordic conference, Linkoping, Sweden, April, 1975.

11. Base metal conductor pastes, a new challenge for the precious metal systems, John H. Wood, General Dynamics, Pomona, Ca. Presented ISHM, Vancouver, B.C., Canada, October, 1976.

12. Glass bonded resistor compositions containing refractory metal nitrides and refractory metal, U.S. Pat. 3384087 C. Y. D. Huang and K. M. Merz, IRC, Inc., Phila., Pa.

13. A copper thick film metallization paste, John D. Grier, Sr., Cermalloy Div., Bala Electronics Corp., W. Conshohocken, Pa. Presented ISHM, Vancouver, B.C., Canada, October, 1976.

14. Copper: a superior solution for thick film multilayers, Karel Kurzweil, Francoise Franconville, Compagnie Honeywell Bull, St. Ouen, France. Presented ISHM, Orlando, Fla., October, 1975.

15. A copper metallization and low $\mathrm{K}$ dielectric system for thick film multilayers, Frank K. Patterson, et al, Dupont Co., Wilmington, Del. Presented ISHM, Vancouver, B.C., Canada, October, 1976.

16. A high quality, base metal, thick film resistor system, A. S. Laurie, Electrical Research Assn., Leatherhead, England. Presented ECC, Washington, D.C., May, 1973.

17. Ultrasonic wire bonding to thick film copper, H. K. Kessler, NBS Special Quarterly Reports, pp. 57-59, October, 1973-March, 1974. 

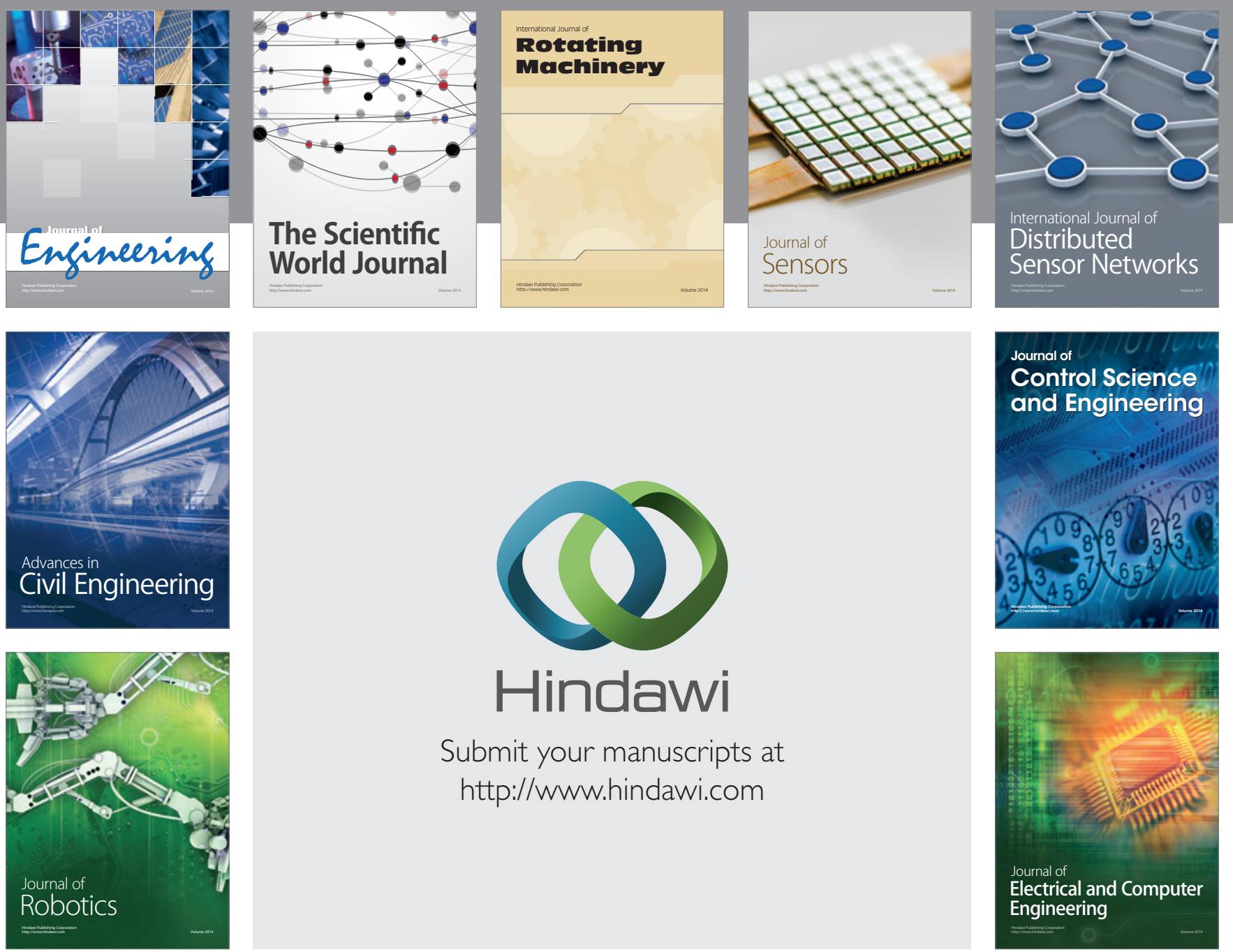

Submit your manuscripts at

http://www.hindawi.com
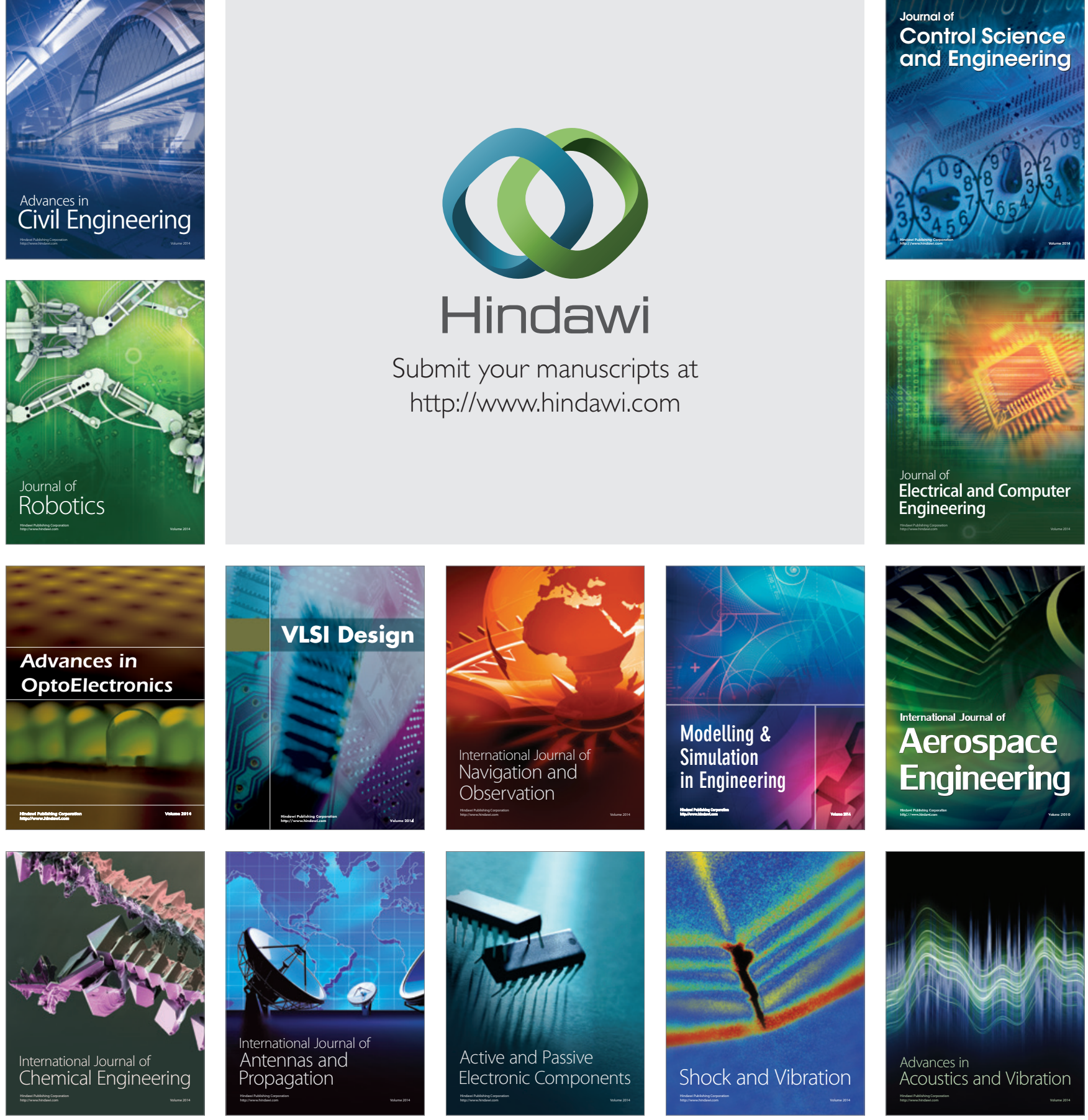